\title{
MENINGKATKAN KETERAMPILAN MOTORIK HALUS ANAK MELALUI TEKNIK MOZAIK
}

\author{
Farah Rizkita Putri, Rudiyanto, I Gusti Komang Aryaprasetya \\ Universitas Pendidikan Indonesia, Jln. Setiabudhi no. 229 Bandung \\ e-mail: Farahrizkita67@gmail.com
}

\begin{abstract}
Abstrak : Improve Fine Motor Skills of Children Through the Mosaic Technique. This research take issue from Raudatul Athfal Nurul huda. 4 out of 10 children not control fine motor skills in terms of putting or holding an object by use of the hands involving the movement of the eye and hands, childrens not yet ready for coordination between the right hand with the left hand. A technique used teacher are less varied, so it is not fully stimulate child to train their fine motor skills. Therefore, the purpose of this research to try to improve fine motor skills the used different technique than usual, that would give a positive impact on children through mozaik engineering. The methodology that was used in this research is research class action. While engineering and instrument data collection in the form of observation, interviews and documentation. Data analysis used is the reduction of the data. The subjects of research from Raudatul Athfal Nurul huda as many as 10 childrens. The research starting from 03th august 2015 until 27th august 2015. Research done in three cycle there are in every single cycle has two action. The result of research showed fine motor skill has increased. The lab data showed there has been increasing the achievement of the development was very good until $83 \%$ at the end cycle III. Based on the survey a conclusion can be drawn that mozaik engineering can be used as recommendations as one way to improved the fine motor skills of childrens.
\end{abstract}

Keywords : fine motor skills and mozaic technique

Abstrak : Meningkatkan Keterampilan Motorik Halus Anak melalui Teknik
Mozaik Penelitian ini mengangkat masalah dari Raudatul Athfal Nurul huda belum
sepenuhnya memenuhi tahapan perkembangan seusianya. Dapat dibuktikan 4 dari 10
anak belum tercapainya koordinasi gerakan motorik halus dalam hal kegiatan
meletakan/memegang suatu objek dengan mengunakan jari tangan dan mengkoordinasi
gerakan mata dengan tangan, anak belum siap untuk koordinasi gerak tangan kanan dan
tangan kiri atau antara jari-jemari. Teknik yang digunakan oleh guru kurang bervariasi
sehingga belum sepenuhnya merangsang agar anak melatih keterampilan motorik
halusnya. Oleh karena itu, tujuan penelitian ini mencoba meningkatkan keterampilan
motorik halus anak menggunakan teknik yang berbeda dari biasanya sehingga dapat
memberikan dampak positif bagi anak melalui teknik mozaik. Metode yang diunakan
dalam penelitian ini yaitu penelitian tindakan kelas. Sedangkan teknik dan alat
pengumpul data berupa observasi, wawancara dan dokumentasi. Analisis data yang
digunakan pada penelitian ini adalah reduksi data. Subjek penelitian kelompok A di
Raudatl Athfal Nurul Huda sebanyak 10 anak. Pelaksanaan penelitian dimulai dari 3
Agustus 2015 hingga 27 Agustus 2015 . Penelitian dilakukan melalui tiga siklus dan
setiap siklus terdiri dari dua tindakan. Hasil penelitian menunjukan perkembangan
motorik halus anak terdapat peningkatan yang cukup baik. Data hasil penelitian yang
telah dilaksanakan menunjukan terdapat peningkatan pencapaian perkembangan pada
kategori berkembang sangat baik (BSB) sebesar 83\% pada akhir Siklus III.
Berdasarkan penelitian tersebut diperoleh kesimpulan bahwa teknik mozaik dapat 
dijadikan rekomendasi sebagai salah satu cara untuk meningkatkan keterampilan motorik halus anak.

Kata kunci: motorik halus dan teknik mozaik

Perkembangan motorik menjadi salah satu perhatian penting. Motorik merupakan pengendalian gerakan tubuh manusia melalui susunan saraf, otot, otak dan spinal cord Perkembangan motorik sangat dipengaruhi oleh organ otak. Otaklah yang menjadi setir gerakan apa yang akan anak akan lakukan. Semakin matangnya perkembangan motorik anak maka system saraf otak yang akan mengatur otot yang berpotensi sebagai cara berkembangnya kemampuan anak. Perkembangan motorik dibagi menjadi dua yaitu motorik kasar dan motorik halus.

Motorik halus merupakan gerakan yang menggunakan koordinasi antara mata, tangan, lengan dan tubuh lain secara bersamaan yang dipengaruhi oleh kesempatan belajar dan latihan. Motorik halus dapat distimulasi melalui cara menyusun balok, bermain pasir, mengancingkan baju, mengumpulkan benda, menggunting, mewarnai, menarik garis, menempel dan lain-lain. Pengembangan motorik halus sebagai salah satu penunjang untuk kelangsungan hidup anak di masa yang akan datang yaitu kegiatan menulis. (Seba dan Gatot, 2013, hlm. 31).

Kemampuan motorik halus yang dimiliki setiap anak berbeda tingkatannya setiap individu. Anak usia empat tahun bisa dengan mudah menarik garis vertikal sementara yang lainnya akan bisa mungkin setelah menginjak usia selanjutnya. Sebaiknya peran guru dan orang tua mengetahui permasalahan dan tindakan apa yang harus diberikan untuk meningkatkan keterampilan motorik halus anak. Permasalahan yang sering terjadi dilapangan antara lain kurang terkoordinasi guru dengan orang tua, misalnya anak di sekolah terbiasa melakukan kegiatan mandiri tetapi jika di rumah masih sering dibantu oleh orang tua atau pengasuh, kurang terciptanya ruang untuk anak berekplorasi pada anak, kurang konsisten untuk memberikan stimulus atau rangsangan belajar, guru masih menerapkan pembelajaran yang konvensional seperti, kurangnya informasi mengenai model pembelajaran dan penggunaan teknik yang kurang memunculkan untuk menunjang kegiatan motorik halus,

Mengacu pada fenomena di atas, maka peneliti melakukan pengamatan di Raudatul Nurul Huda. Hasil pengamatan pada kegiatan awal bahwa anak kelompok A pada kesiapan anak 4 dari 10 murid kelas A tersebut memiliki masalah pada perkembangan motorik halus. Dapat dikatakan memiliki masalah karena menurut obervasi yang telah dilakukan oleh peneliti di Raudatul Athfal Nurul Huda bahwa belum tercapainya koordinasi gerakan motorik halus dalam hal kegiatan meletakan/ memegang suatu objek dengan mengunakan jari tangan dan mengkoordinasi gerakan mata dengan tangan. Kesiapan pendidik untuk mengembangkan keterampilan motorik halus juga masih kurang dengan dibuktikan melalui paparan penjelasan hasil observasi lapangan. Dapat dilihat bahwa pengembangan motorik halus pada Raudatul Athfal tersebut masih menggunakan metode pembelajaran konvensional.

Permasalahan yang terkait dalam kurangnya kemampuan anak dalam mengembangkan motorik halus disebabkan oleh sekolah hanya menggunakan buku dan 
lembar kerja siswa, penggunaan teknik yang kurang menarik minat anak dan penggunaan media yang kurang variatif sehingga kurang ruang untuk mengembangkan kemampuan motorik halus. Selain itu, peneliti juga melakukan wawancara untuk mengetahui kondisi perkembangan motorik halus pada guru kelompok A bahwa kegiatan meningkatkan keterampilan motorik halus anak hanya dilakukan sekali saja dan tidak terjadi pengulangan atau melibatkan beberapa kegiatan yang dapat dikolaborasikan.

Berbagai macam teknik yang sekarang telah ditemukan untuk mengembangkan keterampilan motorik halus anak, salah satunya dengan menggunakan teknik mozaik. Pengembangan keterampilan motorik halus biasanya terkait dengan kegiatan karya seni. Berkarya seni secara tidak langsung sangat membantu pendidikan melalui penerapan metode pembelajaran. Anak akan lebih mudah belajar tentang sesuatu bila melalui seni karena kegiatan seni pada anak seperti halnya sedang bermain, sehingga dalam proses pembelajaran pun akan berlangsung dengan menyenangkan.

Kegiatan kreasi seni rupa anak berupa kegiatan menggambar, melukis, mencetak dan juga anak dapat melakukan kreasi seni sesuai dengan cara menempelkan jenis bahan tertentu disuatu bidang. Sesuai dengan jenis dan bentuk bahan yang ditempelkan kreasi seni rupa dapat dibedakan menjadi 3 bagian yaitu mozaik, montase dan kolase. Sebagai mana menurut Evan Sukardi (2008, hlm. 5.2) Pemahaman tentang pengetahuan dan keterampilan kreasi seni kolase, mozaik dan montase merupakan hal yang sangat penting bagi seorang guru taman kanakkanak, karena proses keterampilan kolase, mozaik dan montase bagi anak usia taman kanak-kanak merupakan kegiatan bermain sekaligus berkreasi seni dalam kegiatan anak.

Berdasarkan Observasi di Raudatul Athfal Nurul Huda ditemukan indikasi pada pembelajaran keterampilan motorik halus ini kurang maksimal. Hal ini disebabkan oleh penggunaan teknik yang biasa saja, motivasi guru pada anak dalam melaksanakan kegiatan yang berhubungan motorik halus kurang maksimal. Padahal menurut Suyanto (2005, hlm. 51) Motorik halus adalah gerakan halus yang melibatkan bagianbagaian tertentu saja yang dilakukan oleh otot-otot kecil saja, karena tidak memerlukan tenaga tetapi memerlukan koordinasi yang cermat.

\section{METODE}

Metode penelitian yang akan digunakan pada penelitian yang digunakan dalam pelaksanaan penelitian ini adalah penelitian tindakan kelas kolaboratif. Metode kolaboratif digunakan karena penulis melakukan kolaborasi dengan guru kelas. Model penelitian tindakan kelas ini menggunakan model yang dikemukakan oleh Kemmis \& Mc Targart.

Variabel dalam penelitian ini adalah variabel terikat dan variabel bebas. Variabel terikat yaitu keterampilan motorik halus anak. Sedangkan variabel bebasnya adalah teknik mozaik.

Populasi penelitian ini merupakan Kelompok A di Raudatul Athfal Nurul Huda Sarijadi Bandung. Kelompok A berjumlah 15 orang siswa tetapi hanya 10 siswa sja yang dijadikan objek penelitian karena, 5 siswa masuk pada tengah penelitian sedang berlangsung.

Instrumen penelitian ini menggunakan menggunakan pedoman observasi dengan mengacu pada tingkat pencapaian perkembangan motorik halus anak usia 4-5 
tahun dalam Peraturan Menteri Pendidikan Nasional no.58 tahun 2009 dan disesuaikan dengan indikator perkembangan anak usia dini Pemendikbud kurikulum 2013 PAUD, menlakukan wawancara pada kepala sekolah dan guru, catatan lapangan setiap tindakan dan dokumentasi. Keterampilan motorik halus yang dipakai untuk instrument ada 3 aspek, yaitu menulis, menggunting dan menggambar. Sebelum disebarkan ke lapangan, dilakukan tahapan uji instrumen, yaitu uji konstruk terhadap 2 orang ahli.

Pada penelitian ini, teknik analisis data yang digunakan adalah reduksi data dan tampilan data berupa catatan setiap siklussiklus penelitian, tabel dan grafik serta dokumentasi hasil karya.

\section{HASIL DAN PEMBAHASAN}

\section{Hasil Peningkatan Keterampilan Motorik Halus anak melalui teknik mozaik}

Hasil pemaparan siklus I, siklus II dan siklus III dapat disimpulkan adanya peningkatan yang cukup signifikan. Peningkatan hasil observasi digambarkan melalui dagram hasil observasi terhadap keterampilan motorik halus sebelum diberikan tindakan, keterampilan motorik halus melalui teknik mozaik pada siklus I, keterampilan motorik halus melalui teknik mozaik pada siklus II dan keterampilan motorik halus melalui teknik mozaik pada siklus III Adapun gambaran peningkatan keterampilan motorik halus tersebut dapat dilihat dalam diagram berikut:

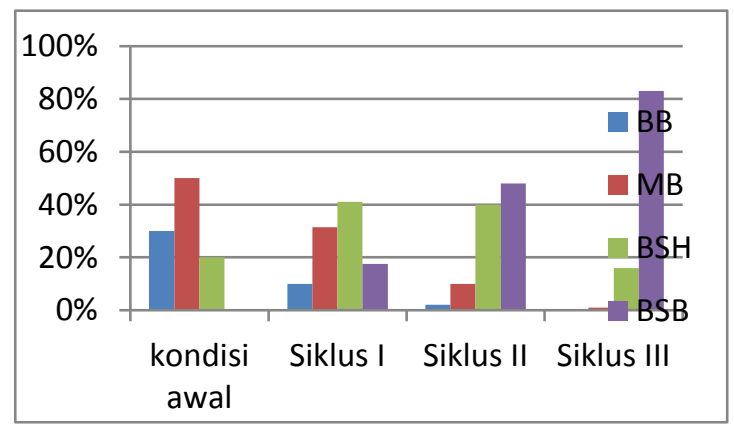

\section{Diagram 1. Kondisi pra siklus, siklus I,} Siklus II dan Siklus III

Berdasarkan diagram tersebut terjadi peningkatan pada semua kategori setiap siklusnya. Berikut merupakan pemaparan hasil persentase setiap kategori pada masingmasing siklus. Kondisi awal (pra siklus) menunjukan kategori belum berkembang (BB) 30\%, kategori mulai berkembang (MB) $50 \%$, kategori berkembang sesuai harapan (BSH) 20\% dan kategori berkembang sangat baik 0\%. Siklus I menunjukan peningkatan keterampilan motorik halus ditunjukan pada kategori Berkembang sangat baik (BSB) $17,5 \%$, kategori berkembang sesuai harapan (BSH) 41\%, kategori mulai berkembang (MB) menurun sebanyak 31,5\% dan kategori belum berkembang (BB) menurun sebanyak $10 \%$.

Peningkatan mulai meningkat pada Siklus II yaitu kategori berkembang sangat baik (BSB) 48\%, kategori berkembang sesuai harapan $(\mathrm{BSH}) 40 \%$, kategori mulai berkembang (MB) 10\% dan kategori belum berkembang $2 \%$. Peningkatan cukup signifikan terjadi pada siklus III, berikut pemaparan pada setiap kategori. Kategori berkembang sangat baik (BSB) pada kondisi awal $0 \%$ dan meningkat cukup signifikan pada akhir siklus III menjadi $83 \%$. Kategori berkembang sesuai harapan (BSH) pada kondisi awal $20 \%$ pada akhir siklus III menjadi 16\%. Kategori Mulai berkembang (MB) pada kondisi awal 50\% pada akhir siklus III menjadi 1\%. Kategori Belum berkembang (BB) pada kondisi awal 30\% dan menunjukan penurunan pada akhir siklus III menjadi $0 \%$.

Kondisi awal keterampilan motorik halus di Raudatul Athfal Nurul Huda 
Berdasarkan pengamatan awal kondisi keterampilan motorik halus melaui teknik mozaik dapat dikategorikan masih rendah, hal tersebut dapat dibuktikan pada observasi kondisi awal keterampilan motorik halus anak kelas A di Raudatul Athfal Nurul Huda. Dapat dikategorikan rendah karena masih banyak anak yang belum mendapat fasilitas menggunakan metode atau teknik yang tepat dan menunjang untuk mengembangkan koordinasi gerak tangan dan mata. Oleh karena itu anak harus mendapat stimulus yang tepat sehingga keterampilan motorik halusnya akan berkembang sesuai tahapan usianya. Berikut data anak yang belum berkembang (BB) Fz, Ry dan $\mathrm{Nj}$. Sedangkan yang masuk kategori Mulai berkembang (MB) adalah At, Gm, Rd, Zf dan Zh. Serta yang termasuk kategori Berkembang sesuai harapan adalah Kh dan Ft. sementara anak yang dikategorikan berkembang sangat baik belum ada.

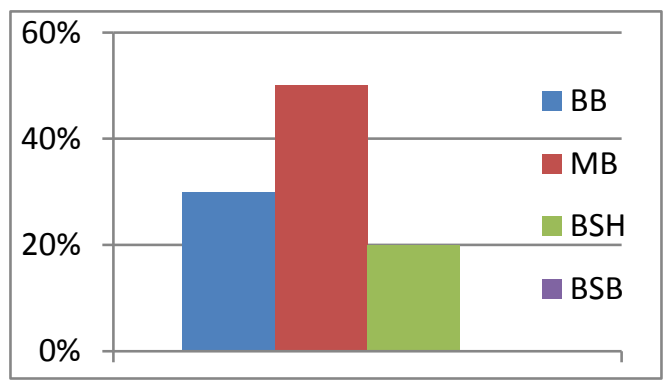

\section{Diagram 2. Kondisi awal motorik halus anak di RA Nurul Huda kelompok A}

\section{Pelaksanaan teknik mozak untuk meningkatkan kemampuan motorik halus anak}

Meningkatkan keterampilan motorik halus melalui teknik mozaik dilaksanakan dengan dalam tiga siklus yaitu siklus I, siklus II dan siklus III. Dimana setiap siklusnya terdapat dua tindakan yaitu siklus I tindakan I dan siklus I tindakan II, siklus II tindakan I dan siklus II tindakan II dan siklus III tindakan I dan siklus III tindakan II.

Kegiatan pada setiap siklus dilaksanakan secara bertahap. Sebelum melakukan tindakan, peneliti berdiskusi dengan guru kelas mengenai perencanaan tindakan kemudian dari hasil perencanaan tersebut, peneliti dan guru kelas menyusun rencana kegiatan harian dan skenario pembelajaran sebagai acuan bagi pelaksana dari setiap tindakan yang akan dilakukan. Setelah pembelajaran dilaksanakan, peneliti dan guru kelas melakukan refleksi dengan cara evaluasi proses pembelajaran dan melihat hasil karya anak pada setiap tindakan.

Penggunaan teknik mozaik bukan hal baru bagi guru di Raudatul Athfal Nurul huda tetapi menurut hasil wawancara guru jarang sekali memakai teknik-teknik yang beraneka ragam karena kegiatan yang dilakukan pada hari yang sama dan itu berlaku untuk semua kelas. Ini merupakan kekurangan yang dimiliki guru untuk bereksplorasi menggunakan teknik yang bermacam-macam khususnya teknik mozaik. Oleh sebab itu, peneliti menggunakan teknik mozaik dari tingkatan mudah sampai sulit. Penggunaan teknik mozaik ini diterapkan dari siklus I sampai siklus II dan pada setiap tindakannya.

Awal pelaksanaan Siklus I tindakan I, anak mulai mencoba membuat garis sederhana menggunakan pensil.Kemudian anak mencoba teknik mozaik menggunakan teknik sobek agar anak mulai berkenalan terlebih dahulu dengan teknik yang diberikan guru. Pada pelaksanaan siklus I tindakan II anak telah diberikan alat bantu berupa gunting untuk memudahkan membuat potongan kertas yang akan ditempel dan guru menggunakan kuas beserta cat air untuk memudahkan anak melatih membuat garis sederhana. Media ini 
digunakan agar anak tidak cepat bosan yang hanya membuat garis menggunakan pensil saja tetapi bisa juga menggunakan kuas dan anak juga diberikan garis putus-putus agar anak mudah untuk melatih mengingat cara membuat garis horizontal, vertikal, diagonal dan lingkaran. Sebagaimana yang diungkapkan oleh (Sumantri, 2005, hlm. 121) "Pengembangan keterampilan motorik halus akan berpengaruh pada kesiapan anak untuk menulis. Banyak kegiatan motorik halus diajurkan meskipun penggunaan tangan secara utuh belum mungkin tercapai. Koordinasi motorik halus antara tangan dan mata dikembangkan melalui permainan seperti mencocok, menggambar, mewarnai, meronce dan menggunting." Teknik mozaik merupakan salah satu teknik yang memerlukan pengabungan antara unsur menggambar, menggunting dan menempel agar terciptanya hasil karya yang menarik.

Siklus II tindakan I guru dan peneliti mencoba dengan membuat mozaik 3D dengan perbedaan tugas setiap anak, hal ini diberikan agar anak dapat merasakan perbedaan menggunakan teknik mozaik 2D dan 3D. Kemudian pada siklus II tindakan II guru memberikan teknik mozaik dengan cara memberikan alat bantu gunting dan anak akan menggunting pola segitiga, persegi dan lingkaran. Hal ini dilakukan karena melihat perkembangan motorik anak dari siklus I tindakan I hingga siklus II tindakan I, anak sudah luwes memakai alat bantu berupa gunting. Penggunaan gunting dengan cara anak menggunting bebas terlebih dahulu bertujuan agar anak pada tindakan berikutnya menggunting kertas dengan beberapa pola. Serta guru juga melihat perkembangan anak yang dibantu dengan membuat garis sederhana dengan garis putus-putus, pada saat siklus II tindakan II guru dan peneliti mencoba anak untuk membuat satu huruf yang anak paling sukai, jadi tidak ada unsur paksaan dari guru untuk membuat huruf apa saja.

Hasil refleksi setiap siklus dikaji ulang oleh peneliti dan melihat peningkatan dari siklus I sampai siklus II maka peneliti memutuskan untuk melanjutkan pada siklus III. Perencanaan pada siklus III dilakukan bersama guru kelas adalah menggunakan anggota tubuh sebagai salah satu sarana media untuk mempermudah anak membuat mozaik. Oleh karena tema di Raudatul Athfal Nurul Huda pada saat Siklus III adalah mengenai anggota tubuh, jadi guru kelas dan peneliti memutuskan untuk menggunakan tangan dan kaki anak sebagai alat bantu untuk membuat sketsa dan juga sub tema untuk dua tindakan. Kemudian guru kelas dan peneliti juga membuat perencanaan pada tindakan I menggunakan pola persegi untuk pola pertama dan pada tindakan II menggunakan pola lingkaran untuk pola kedua.

\section{Peningkatan Keterampilan Motorik Halus Anak}

Pada pelaksanaan siklus I tindakan I proses pembelajaran berlangsung belum kondusif karena peran guru dan peneliti masih dominan dan banyak anak yang masih memerlukan bantuan dalam melakukan teknik mozaik, hal ini terjadi karena teknik mozaik merupakan teknik yang baru digunakan guru untuk melatih keterampilan motorik halus anak. Sedangkan pada pelaksanaan siklus I tindakan II, guru menjelaskan lebih luwes dan juga tema untuk membuat teknik mozaik lebih konkret karena pada hari tersebut tentang perempuan dan laki-laki, serta anak diberikan alat bantu yaitu gunting dan media berupa kuas dan cat air , hal ini dapat menstimulasi minat anak dalam pelaksaan teknik mozaik. 
Pelaksanaan Siklus II tindakan I guru dan peneliti membuat suasana belajar menggunakan teknik mozaik lebih menyenangkan karena menyambut hari kemerdekaan dan juga membuat teknik mozaik dalam bentuk 3D. Melihat perkembangan anak yang cukup signifikaan pada siklus II tindakan II guru dan peneliti mencoba pada anak untuk menggunting kertas yang memiliki pola segitiga, persegi dan lingkaran. Hal ini diberikan pada anak karena melihat anak sudah bisa melewati proses menggunting bebas yang cukup baik dan dilihat dari proses pengulangan proses menggunting siklus I tindakan II dan siklus II juga agar anak mampu percaya diri pada kemampuan motorik halusnya.

Proses motorik halus melalui teknik mozaik pada siklus III terlihat peningkatan yang signifikan. Hal ini dapat terlihat dari media yang telah direncanakan oleh guru kelas dan peneliti menggunakan tangan dan kaki anak sebagai alat bantu membuat sketsa, sehingga anak dapat menigkatkan keberhasilan dalam membuat garis horizontal, vertikal dan diagonal. Proses mengunting pun mengalami peningkatan, karena hasil refleksi dari siklus II menggunting pola telah di coba dan pada siklus III tindakan I anak dberikan pola persegi sedangkan siklus III tindakan II anak diberikan pola lingkaran.

Berdasarkan hasil data keseluruhan akhir siklus III tindakan II dapat disimpulkan kategori Berkembang sangat baik meningkat signifikan dari kondisi awal di siklus I sebanyak 0\% menjadi $83 \%$. Kategori Berkembang sesuai harapan pada kondisi awal adalah $20 \%$ pada akhir siklus III menjadi $16 \%$. Kategori Mulai berkembang pada kondisi awal 50\% menunjukan penurunan pada akhir siklus III menjadi $1 \%$. Kategori belum berkembang pada kondisi awal 30\% menurun pada akhir siklus III menjadi $0 \%$.

Hal ini juga dikuatkan melalui penelitian Nariasih (2014) yang menjelaskan bahwa teknik mozaik dapat melatih pencapaian perkembangan dengan cara anak menempel tepat pada gagasan gambar yang telah anak buat kemudian memerlukan keterampilan dan koordinasi antara mata dengan tangan. Kelenturan tangan anak dalam memegang alat dan bahan yang akan digunakan dalam pmbelajaran. Teknik mozaik merupakan salah satu dari banyak cara untuk anak lebih melatih keterampilan motorik halus.

Kondisi akhir dari siklus III pada penelitian ini yaitu kemampuan anak mengalami peningkatan yang cukup signifikan karena mendapat stimulasi dengan menggunakan teknik mozaik dalam proses pembelajaran untuk menstimulasi keterampilan motorik halus anak dan memberikan kesempatan anak untuk memperoleh pembelajaran yang menarik dan menyenangkan sehingga dapat menghasilkan pengalaman bagi anak. Hal ini ditujukan bahwa menggunakan teknik mozaik memberikan dampak positif bagi kegiatan pembelajaran motorik halus pada peningkatan keterampilan motorik halus di Raudatul Athfal Nurul Huda. Anak terlihat banyak belajar mengkolaborasikan beberapa kegiatan menjadi suatu hasil pembelajaran yang menarik, misalnya kegiatan membuat sketsa gambar menggunakan cat air kemudian kegiatan menggunting kertas lalu menempel potongan kertas pada sketsa tersebut. Penggunaan teknik mozaik ini dapat meningkatkan keterampilan motorik halus anak dibandingkan metode pembelajaran konvensional yang hanya menggunakan lembar kerja siswa dan buku tulis yang memberikan dampak negatif pada 
perkembangan keterampilan motorik halus anak.

\section{SIMPULAN}

Berdasarkan hasil penelitian dalam menjawab rumusan masalah dan tujuan penelitian, maka data penelitian menghasilkan beberapa kesimpulan, yaitu:

1.Keterampilan motorik halus pada anak kelompok A di Raudatul Athfal Nurul Huda sebelum dilaksanakan teknik mozaik menunjukan bahwa anak-anak pada umumnya memiliki keterampilan motorik halus yang belum mencapai hasil signifikan.

2.Teknik yang diberikan pada anak untuk meningkatkan keterampilan motorik halus pada Siklus I, Siklus II dan Siklus III menggunakan teknik mozaik. Tahapan dalam pelaksanaan teknik mozaik diantaranya membuat sketsa gambar, membuat potongan kertas dan menempel potongan kertas pada sketsa gambar.

3.Keterampilan motorik halus anak di Raudatul Athfal Nurul Huda yang telah dilaksanakan sebanyak tiga siklus dengan dua tindakan per siklusnya. Dilihat dari hasil siklus I kategori BSB sebesar 17,5\%, pada Siklus II kategori BSB sebesar $48 \%$ dan menunjukan peningkatan yang signifikan pada Siklus III sebanyak $83 \%$.

\section{DAFTAR PUSTAKA}

Evan, Sukardi \& Pamadhi, H. 2008. Seni Keterampilan Anak. Jakarta: Universitas Terbuka

Menteri Pendidikan Nasional. (2009). Peraturan Menteri Pendidikan Nasional Republik Indonesia nomor 58 tahun 2009 tentang Standar Pendidikan Anak Usia Dini

Nariasih, Ni wayan. (2014). Penerapan Metode Pemberian Tugas Untuk Meningkatkan Kemampuan Motorik Halus Anak Usia Dini. Jurnal Pendidikan Guru Pendidikan Anak Usia Dini Voulme 2 No 1 tahun 2014

Seba \& Gatot. (2013). Belajar Motorik. Bandung: Sekolah Tinggi Keguruan dan Ilmu Pendidikan Pasundan Cimahi

Seba \& Gatot. (2013). Perkembangan Motorik. Bandung: Sekolah Tinggi Keguruan dan Ilmu Pendidikan Pasundan Cimahi

Sumantri. (2005). Model Pengembangan keterampilan motorik anak usia dini. Jakarta: Departemen Pendidikan Nasional

Suyanto. (2005). Pengembangan Kreativitas Senirupa Anak TK.Jakarta: Departemen Pendidikan Nasional. 